\title{
Identification of a Novel Herpesvirus Associated with a Penile Proliferative Lesion in a Beluga (Delphinapterus leucas)
}

\begin{abstract}
Christian Bellehumeur, ${ }^{1}$ Stéphane Lair, ${ }^{2}$ Carlos H. Romero, ${ }^{3}$ Chantale Provost, ${ }^{1}$ Ole Nielsen, ${ }^{4}$ and Carl A. Gagnon ${ }^{1,5}{ }^{1}$ Laboratoire des maladies infectieuses virales vétérinaires, Faculté de médecine vétérinaire, Université de Montréal, 3200 Sicotte, St-Hyacinthe, Québec J2S 7C6, Canada; ${ }^{2}$ Centre québécois sur la santé des animaux sauvages/Canadian Cooperative Wildlife Health Centre, Faculté de médecine vétérinaire, Université de Montréal, 3200 Sicotte, St-Hyacinthe, Québec J2S 7C6, Canada; ${ }^{3}$ Department of Infectious Diseases and Pathology, College of Veterinary Medicine, University of Florida, 2015 SW 16th Avenue, Gainesville, Florida 32610, USA; ${ }^{4}$ Department of Fisheries and Oceans Canada, 501 University Crescent, Winnipeg, Manitoba R3T 2N6, Canada; ${ }^{5}$ Corresponding author (email: carl.a.gagnon@umontreal.ca)
\end{abstract}

ABSTRACT: The carcass of an adult male beluga (Delphinapterus leucas) was found beach cast in 2008 on the shore of the St. Lawrence Estuary at Rivière-Ouelle, Quebec, Canada. The carcass was transported to the Faculté de médecine vétérinaire of the Université de Montréal for postmortem examination. Aspiration pneumonia was the probable cause of death. Necropsy revealed a focal papilloma-like penile lesion, characterized by focal mucosal thickening with disorganization of the epithelial layers and lymphoplasmacytic infiltration. A pan-herpesvirus nested PCR assay on frozen tissue from the penile lesion was positive. The PCR product sequencing revealed a partial herpesvirus DNA polymerase (DPOL) gene sequence of 600 nucleotides. Its nearest nucleotide identity was with the partial DPOL gene of an alphaherpesvirus, bovine herpesvirus 5 (79.5\% identity). It also shared high identity with several other marine mammal herpesviruses ( 50.2 to $77.3 \%$ identity). This new herpesvirus was tentatively named beluga whale herpesvirus (BWHV). Virus isolation was unsuccessful. The pathogenic potential of BWHV is unknown, but the evaluation of archived tissues suggests that the virus is endemic in the St. Lawrence Estuary beluga population.

Key words: Beluga, beluga whale herpesvirus, cetaceans, Delphinapterus leucas, marine mammals, mucosal lesions, penile papilloma.

On 3 May 2008, the carcass of an adult male beluga (Delphinapterus leucas), with a Smithsonian Condition Code of 3.5 (Geraci et al. 1993), was found stranded on a shore of the St. Lawrence Estuary near the town of Rivière-Ouelle, Québec, Canada $\left(47^{\circ} 26^{\prime} 00^{\prime \prime} \mathrm{N}, 70^{\circ} 01^{\prime} 00^{\prime \prime} \mathrm{W}\right)$. The carcass was transported the same day to the Faculté de médecine vétérinaire (FMV) of the Université de Montréal (St. Hyacinthe,
Québec, Canada) for postmortem examination. The animal was $428 \mathrm{~cm}$ long and weighed $961 \mathrm{~kg}$. Age was approximately $21 \mathrm{yr}$, based on the number of growth layer groups of dentine using a longitudinal midline section of half tooth (Stewart et al. 2006). A slightly raised, oval lesion $(4 \times 3 \mathrm{~cm})$ of mucosal thickening was detected on the midthird of the penis (Fig. 1). The only other significant macroscopic finding was a large amount of partially digested fish in the first gastric compartment and esophagus. Selected tissues were frozen at $-80 \mathrm{C}$ and submitted for RNA/DNA extraction or were fixed in $10 \%$ neutral buffered formalin and submitted for histopathology. Fixed tissues were embedded in paraffin, sectioned at $5 \mu \mathrm{m}$, stained with hematoxylin-phloxinesaffron, and examined by light microscopy.

Based on microscopic examination of tissues, the cause of death was aspiration pneumonia, characterized by large amounts of foreign material associated with inflammation in the deep airways. The cause of the aspiration is unknown. The penile lesion was formed by a moderate thickening of the mucosa associated with cellular disorganization and characterized by nonparallel arrangements of the deep epithelial layers and formation of elongated projections of epithelial cells into the submucosa (Fig. 2A). Numerous mitotic figures were present in the basal layer. There was moderate multifocal lymphoplasmacytic infiltration of the mucosa and submucosa (Fig. 2B).

Genital lesions similar to that in this beluga have been described in other species 


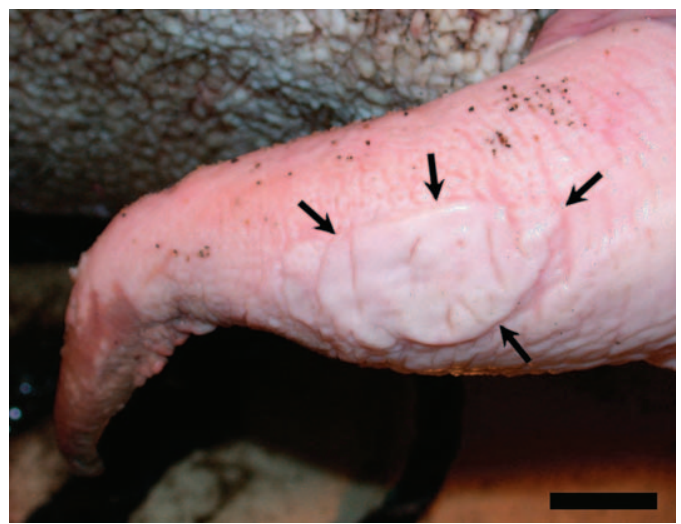

Figure 1. Penis of a beluga whale (Delphinapterus leucas) found stranded on a shore of the St. Lawrence Estuary near Rivière-Ouelle, Québec, Canada, 2008. A well-demarcated slightly raised oval area of mucosal thickening is present on the midthird of the penis (arrows). Bar $=2 \mathrm{~cm}$.

of cetaceans, including common bottlenose dolphins (Tursiops truncatus), Risso's dolphin (Grampus griseus), Burmeister's porpoise (Phocoena spinipinnis), Atlantic white-sided dolphin (Lagenorhynchus acutus), and Blainville's beaked whale (Mesoplodon densirostris). The lesions in these species were associated with herpesviruses (Saliki et al. 2006; van Elk et al. 2009) or papillomaviruses (Van Bressem et al. 1996; Rehtanz et al. 2006; Van Bressem et al. 2007; Gottschling et al. 2011). Herpesviruses have a linear double-stranded DNA genome of around 130-230 kilobases and are classified into three viral subfamilies (Alphaherpesvirinae, Betaherpesvirinae, and Gammaherpesvirinae) composing the family Herpesviridae. Herpesviruses are considered to be host specific. However, most animal species are affected by several distinct herpesviruses (Pellett et al. 2012). Papillomaviruses have a circular doublestranded DNA genome of around 6.8-8.4 kilobases and are classified into 16 genera composing the Papillomaviridae. Papillomaviruses are also considered host specific (Bernard et al. 2012).

Considering the similarity between genital lesions reported in marine mammals and those observed in this beluga, a sample of lesion was tested for herpesvirus and papillomavirus. Papillomaviruses were tested for by PCR using primers FP-L1 (ACT GAT GAA TTT RTA ACA CGC AC) and RP-L1 (ATC ATC TGC ATI GAT TTA GGA TC). Both primers were selected based on a multiple alignment (ClustalW, MegAlign, Lasergene, DNAS-

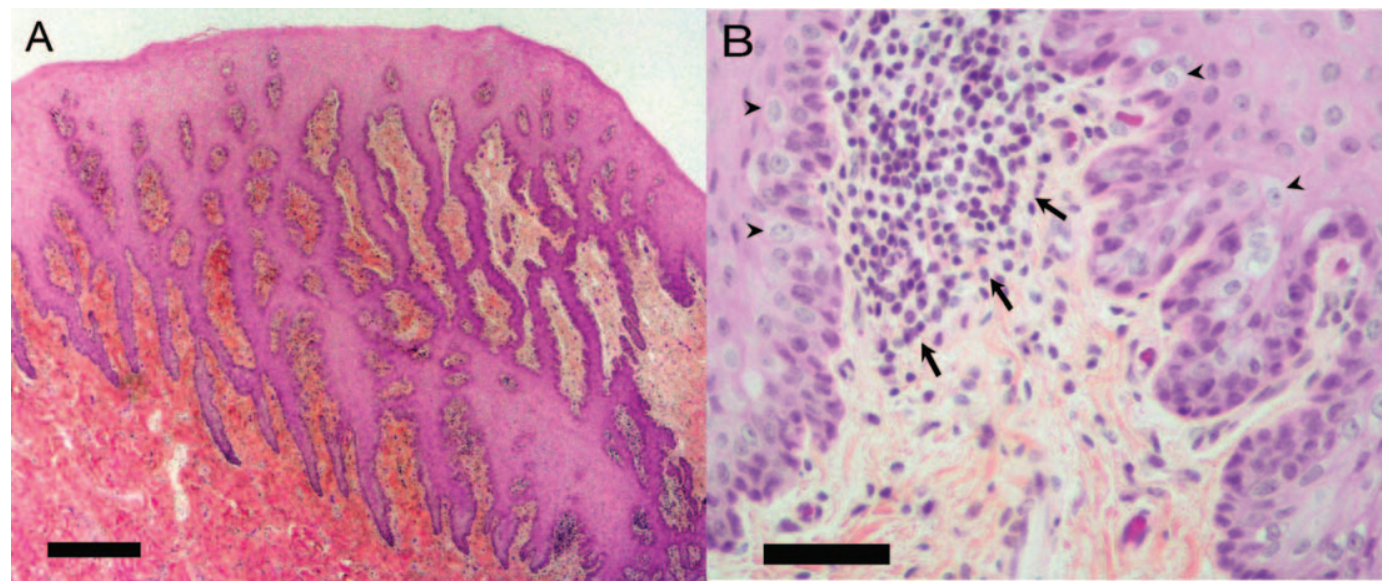

FIgURE 2. Histopathologic examination of the penile mucosal thickening from a beluga whale (Delphinapterus leucas) found stranded on a shore of the St. Lawrence Estuary near Rivière-Ouelle, Québec, Canada. (A) Disorganized formation of elongated projections of epithelial cells in the inflamed submucosa. Bar $=400 \mu \mathrm{m}$. (B) Basal layer of the altered penile mucosa with epithelial cells presenting cytoplasmic vacuolation and chromatin margination (arrowheads). Note lymphoplasmacytic infiltration of the submucosa (arrows). Bar $=50 \mu \mathrm{m}$. Hematoxylin-phloxine-saffron stain. 
TABLE 1. Description of beluga whales found beach cast on the shore of the St. Lawrence Estuary (Canada) between 2003 and 2010 that were tested for herpesviruses and papillomaviruses. All papillomavirus PCRs were negative.

\begin{tabular}{|c|c|c|c|c|c|c|}
\hline Case & $\begin{array}{l}\text { Date of carcass } \\
\text { recovery }\end{array}$ & Sex & $\begin{array}{c}\text { Age } \\
(\mathrm{GLG})^{\mathrm{a}}\end{array}$ & $\begin{array}{l}\text { Stranding } \\
\text { location }\end{array}$ & Type of lesion & $\begin{array}{l}\text { Pan-herpesvirus } \\
\text { nested PCR result }\end{array}$ \\
\hline FMV08-1468944 & 3 May 2008 & Male & 21 & Rivière-Ouelle & Penile papilloma & Positive \\
\hline FMV03-1481253 & $\begin{array}{l}24 \text { November } \\
2003\end{array}$ & Male & 33 & Tadoussac & Focal penile ulcer & Negative \\
\hline FMV04-1481252 & 4 June 2004 & Female & 60 & Port-au-Persil & Ulcerative vulvitis & Positive \\
\hline FMV04-1481254 & $\begin{array}{l}10 \text { October } \\
2004\end{array}$ & Male & 25 & Métis & Ulcerative stomatitis & Positive \\
\hline FMV06-1481250 & 7 July 2006 & Male & 55 & Pointe-au-Père & Carcinoma-urethra & Negative \\
\hline FMV09-1482360 & 1 August 2009 & Male & 49 & Sainte-Flavie & Focal penile ulcer & Positive \\
\hline FMV10-1481255 & $\begin{array}{l}4 \text { November } \\
2010\end{array}$ & Male & 1 & Rimouski & Multifocal penile ulcers & Positive \\
\hline
\end{tabular}

${ }^{a}$ GLG = growth layer groups; one GLG is deposited on the tooth each year (Stewart et al. 2006).

TAR, Madison, Wisconsin, USA) of the major capsid protein L1 gene of bottlenose dolphin papillomavirus 1 (TtPV-1) with GenBank accession No. EU240894, TtPV-3 (EU240895), TtPV-4 (JN709469), and TtPV-7 (JN709472). These primers allowed the amplification of the papillomavirus expected 402-base pair (bp) L1 DNA fragment of common and IndoPacific (Tursiops aduncus) bottlenose dolphins and from a bowhead whale (Balaena mysticetus). No papillomavirus DNA was obtained from the beluga whale lesion tissue. However, herpesvirus DNA was detected using a pan-herpesvirus nested PCR (nPCR), as described by Gagnon et al. (2011). The nPCR targeted the herpesviruses DNA polymerase (DPOL) gene and detects a broad range of herpesvirus species. The herpesvirus PCR product was subsequently sequenced to confirm its genomic relationship to herpesviruses. A 218-nucleotide (nt) amplicon, predicting a 72 amino acid sequence, was obtained and deposited into GenBank (accession No. KF155406). The GenBank Basic Local Alignment Search Tool (BLAST; NCBI 2013) analysis suggested the sequence was related to the alphaherpesviruses (Altschul et al. 1997).

Following detection of the new virus, tentatively named beluga whale herpesvirus (BWHV; strain FMV08-1468944), a retrospective study was done using frozen tissues from belugas found beach cast from 2003 to 2010 along the St. Lawrence Estuary. Tissues were obtained from genital and oral mucosal lesions (Table 1). All were PCR negative for papillomavirus, but four of the six were nPCR herpesvirus positive (Table 1). All PCR products were sequenced, and all DPOL partial nt sequences were $100 \%$ identical to FMV081468944. To increase the DNA viral genome sequence coverage of BWHV, the strongest first step of the nPCR reaction (from FMV10-1481255) was submitted for sequencing. A 600-bp DNA sequence was obtained and deposited into GenBank (accession No. KJ789857).

The nt comparison showed that the nearest identity was with the DPOL gene of bovine herpesvirus 5, an alphaherpesvirus (79.5\%; GenBank accession No. AY261359). This new BWHV also shares nt identity with other marine mammal herpesviruses, such as dolphin herpesvirus (respectively 77.3 , 73.2, and $59.4 \%$ with GenBank accession No. KJ398066, AY757301, and AY952776), Blainville's beaked whale gammaherpesvirus (56.7\%; GenBank accession No. AY949828), and dwarf sperm whale gammaherpesvirus (50.2\%; GenBank accession No. AY949830).

A phylogenetic tree containing 40 herpesvirus DPOL partial nt sequences (with 


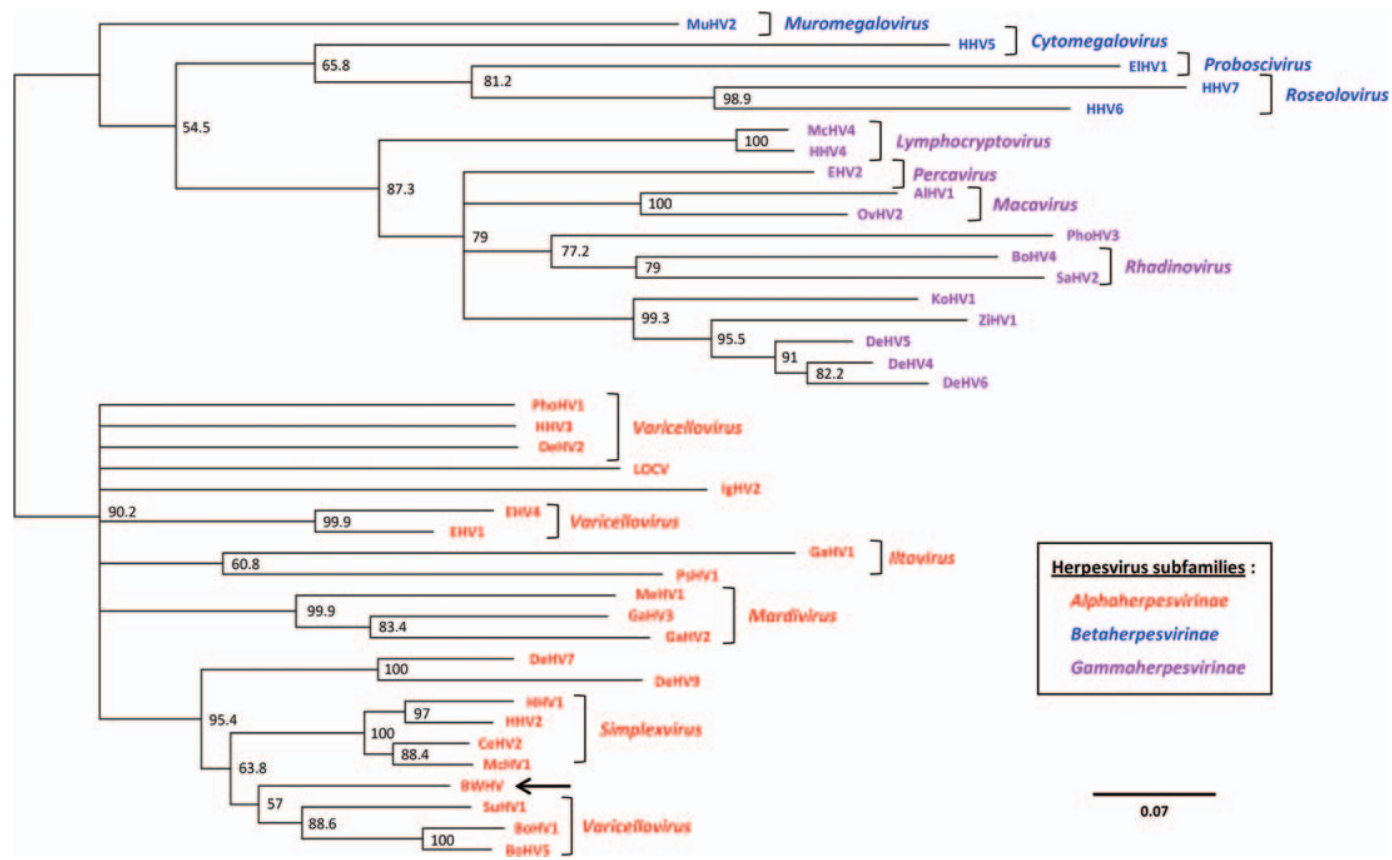

Figure 3. A phylogenetic tree containing 40 herpesvirus DNA polymerase partial nucleotide (nt) sequences (with a 383-nt DNA consensus sequence) was generated by the neighbor-joining method with 1,000 bootstrap replicates with Geneious Pro (version 5.6.6) software using a ClustalW alignment. Bootstrap confidence levels are indicated at the nodes. The horizontal scale indicates the distances between strains; a distance of 0.07 means that the strains possess $93 \%$ nt identity. Herpesvirus subfamilies Alphaherpesvirinae, Betaherpesvirinae, and Gammaherpesvirinae are, respectively, red, blue, and purple. When known, herpesvirus genera are identified by brackets. The arrow indicates the beluga whale herpesvirus (BWHV) strain FMV10-1481255. Sequences from GenBank were selected according to reference strain (Pellett et al. 2012), with the addition of reported sea mammal herpesviruses, and include the following: Alcephaline HV1 (AlHV1; NC_002531); bovine HV1 (BoHV1; NC_001847); BoHV4 (NC_002665); BoHV5 (NC_005261); BWHV (KJ789857); Cercopithecine HV2 (CeHV2; AY714813); Delphinid HV (DeHV2; GQ429149); DeHV4 (AY952777); DeHV5 (AY952776); DeHV6 (DQ288666); DeHV7 (AY608707); DeHV9 (GQ429151); Elephantid HV1 (ElHV1; AF322977); Equid HV1 (EHV1; NC_001491); EHV2 (NC_001650); EHV4 (NC_001844); Gallid HV1 (GaHV1; NC_006623); GaHV2 (NC_002229); GaHV3 (NC_002577); Human HV1 (HHV1; NC_001806); HHV2 (NC_001798); HHV3 (NC_001348); HHV4 (NC_007605); HHV5 (NC_006273); HHV6 (NC_001664); HHV7 (NC_001716); Iguanid HV2 (IgHV2; AY236869); Kogiid HV1 (KoHV1; AY949830); loggerhead orocutaneous HV (LOCV; EU004542); Macacine HV1 (McHV1; NC_004812); McHV4 (NC_006146); Meleagrid HV1 (MeHV1; NC_002641); Murid HV2 (MuHV2; NC_002512); Ovine HV2 (OvHV2; NC_007646); Phocid HV1 (PhoHV1; U92269); PhoHV3 (DQ093191); Psittacid HV1 (PsHV1; NC_005264); Saimiriine HV2 (SaHV2; NC_001350); Suid HV1 (SuHV1; NC_006151); and Ziphiid HV1 (ZiHV1; AY949828).

a 383-nt DNA consensus sequence) was generated by the neighbor-joining method, with 1,000 bootstrap replicates with Geneious Pro (version 5.6.6; Biomatters 2014) using a ClustalW alignment (Fig. 3). Sequences retrieved from GenBank were chosen according to reference strains selected from each herpesvirus genus (Pellett et al. 2012), with the addition of several reported marine mam- mal herpesviruses (Saliki et al. 2006; Smolarek Benson et al. 2006; van Elk et al. 2009), including the new BWHV sequence. The phylogenetic tree (Fig. 3) and the BLAST results indicate that BWHV is closely related to the Varicellovirus genus of the Alphaherpesvirinae subfamily and is closely related to two marine mammal herpesviruses (DeHV7 and DeHV9). 
Virus isolations using beluga primary kidney cells (BWK) and harp seal primary kidney cells (PSK.35; Nielsen et al. 1989; Nielsen et al. 2008) were attempted with tissue samples collected from all five herpesvirus-positive belugas. Cells were passaged at a ratio of 1:2, once per week, and fed with fresh medium (Dulbecco's modified Eagle medium/F12 supplemented with penicillin $[200 \mathrm{IU} / \mathrm{mL}]$, streptomycin [200 $\mu \mathrm{g} / \mathrm{mL}]$, gentamycin [250 $\mu \mathrm{g}$ ], and fetal bovine serum [10\%]). Cells were observed daily for at least 30 days, but no cytopathic effect was detected. Cell culture samples from each virus isolation attempt were subsequently tested with the herpesvirus nPCR. All results were negative, and the virus isolation attempts were considered unsuccessful. Possible reasons for the negative isolation attempts include inappropriate cell culture or advanced decomposition of the tissue collected.

We identified a novel alphaherpesvirus in genital and oral lesions in belugas. Although herpesvirus-like particles have been observed by transmission electron microscopy within skin lesions of belugas (Martineau et al. 1988; Barr et al. 1989), no final confirmation or genomic identification as herpesvirus was achieved. To our knowledge, this is the first reported genomic sequence of a beluga herpesvirus. Mucosal lesions of five belugas were positive for BWHV, suggesting that this virus is endemic in the St. Lawrence Estuary population. Alphaherpesviruses are generally associated with blisters and ulcers, which was the case for four of five herpesvirus-positive belugas. However, alphaherpesviruses are generally not associated with papilloma lesions; thus, it is surprising to find one case related to this kind of lesion. Nonetheless, alphaherpesviruses have been reported in other small cetaceans and were associated with skin lesions (Smolarek Benson et al. 2006). After the submission of this paper, herpesviruses were reported in Alaska beluga whales and were found to be similar to our BWHV (GenBank accession No. KJ191536

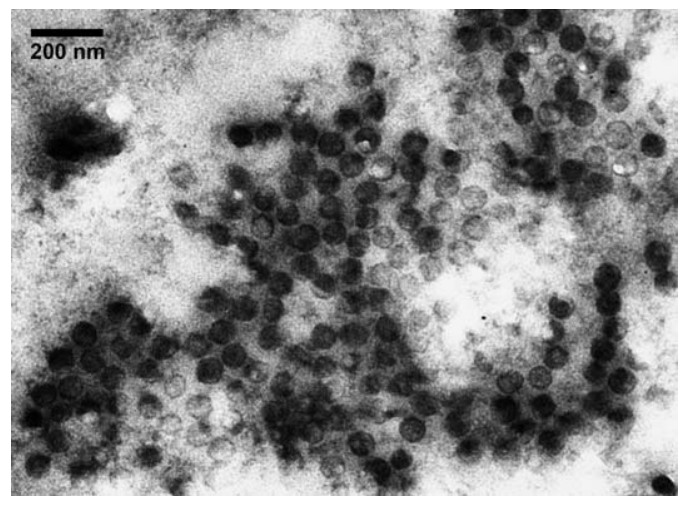

Figure 4. Virus-like particles from a beluga (Delphinapterus leucas) mucosal lesion. Ultrathin sections (70-80 nm) from case FMV10-1481255 were stained with osmium tetroxide (1\%), counterstained with phosphotungstic acid 2\% (pH 7.0), and observed under a transmission electron microscope. $\mathrm{Bar}=200 \mathrm{~nm}$.

to KJ191540 and KF679805), indicating a greater geographic dispersion of BWHV into beluga whale populations. Herpesviruses can establish latent infections, and infections may be asymptomatic. Thus, the presence of BWHV DNA in mucosal lesions could be an incidental finding, not causally associated with the tissue changes we observed. More beluga cases should be studied, and additional work will be needed to determine the causal relationship between BWHV and the mucosal lesions we observed.

To ascertain the involvement of BWHV in mucosal lesions, ultrathin sections of paraffin block-fixed tissues were prepared and observed using a transmission electron microscope (Hitachi HT7700; Rexdale, Ontario, Canada). No herpesvirus-like particles were observed. Surprisingly, viruslike structures of 70-90 nm were observed in case FMV10-1481255 (Fig. 4). Those particles roughly resemble adenovirus virions. Further work is needed to identify those particles. In light of the possible involvement of other viruses (Fig. 4), additional work is needed to determine the causal relationship between BWHV and the mucosal lesions we observed.

This work was supported by the Natural Sciences and Engineering Research Coun- 
cil of Canada discovery grant (to C.A.G.). The beluga pathology program has been supported by Parks Canada, the Canadian Cooperative Wildlife Health Centre, and the Department of Fisheries and Oceans Canada (which also supported the virus isolation attempts). The transmission electron microscopy infrastructure was financially supported by Canada Foundation for Innovation Leaders Fund (to C.A.G.). We are grateful to the Molecular Biology Diagnostic Laboratory of the FMV of the Université de Montréal that conducted the pan-herpesvirus PCR assay.

\section{LITERATURE CITED}

Altschul SF, Madden TL, Schaffer AA, Zhang J, Zhang Z, Miller W, Lipman DJ. 1997. Gapped BLAST and PSI-BLAST: A new generation of protein database search programs. Nucleic Acids Res 25:3389-3402.

Barr B, Dunn JL, Daniel MD, Banford A. 1989. Herpes-like viral dermatitis in a beluga whale (Delphinapterus leucas). J Wildl Dis 25:608-611.

Bernard HU, Burk RD, Devilliers EM, Zur Hausen H. 2012. Family_Papillomaviridae. In: Virus taxonomy: Classification and nomenclature of viruses: Ninth report of the International Committee on Taxonomy of Viruses, King AMQ, Adams MJA, Cadar D, Lefkowitz EJ, editors. Academic Press, Waltham, Massachusetts, pp. 235-248.

Biomatters. 2014. Geneious, www.geneious.com. Accessed August 2014.

Gagnon CA, Tremblay J, Larochelle D, Music N, Tremblay D. 2011. Identification of a novel herpesvirus associated with cutaneous ulcers in a fisher (Martes pennanti). J Vet Diagn Invest 23:986-990.

Geraci JR, Lounsbury VJ. 1993. Marine mammals ashore: A field guide for strandings. Sea Grant College Program, Texas A\&M University, Galveston, Texas, $305 \mathrm{pp}$.

Gottschling M, Bravo IG, Schulz E, Bracho MA, Deaville R, Jepson PD, Van Bressem MF, Stockfleth E, Nindl I. 2011. Modular organizations of novel cetacean papillomaviruses. Mol Phylogenet Evol 59:34-42.

Martineau D, Lagace A, Beland P, Higgins R, Armstrong D, Shugart LR. 1988. Pathology of stranded beluga whales (Delphinapterus leucas) from the St. Lawrence Estuary, Quebec, Canada. J Comp Pathol 98:287-311.

National Center for Biotechnology Information. 2013. NCBI/BLAST home, http://blast.ncbi.nlm. nih.gov/Blast.cgi. Accessed June 2014.
Nielsen O, Kelly RK, Lillie WR, Clayton JW, Fujioka RS, Yoneyama BS. 1989. Some properties of a finite cell line from beluga whale (Delphinapterus Leucas). Can J Fish Aquat Sci 46:6.

Nielsen O, Smith G, Weingartl H, Lair S, Measures L. 2008. Use of a SLAM transfected Vero cell line to isolate and characterize marine mammal morbilliviruses using an experimental ferret model. J Wildl Dis 44:600-611.

Pellett PE, Davison AJ, Eberle R, Ehlers B, Hayward GS, Lacoste V, Minson AC, Nicholas J, Roizman B, Studdert MJ, et al. 2012. Order-Herpesvirales. In: Virus taxonomy: Classification and nomenclature of viruses: Ninth report of the International Committee on Taxonomy of Viruses, King AMQ, Adams MJA, Carstens EB, Lefkowitz EJ, editors. Academic Press, Waltham, Massachusetts, pp. 99-123.

Rehtanz M, Ghim SJ, Rector A, Van Ranst M, Fair PA, Bossart GD, Jenson AB. 2006. Isolation and characterization of the first American bottlenose dolphin papillomavirus: Tursiops truncatus papillomavirus type 2. J Gen Virol 87:3559-3565.

Saliki JT, Cooper EJ, Rotstein DS, Caseltine SL, Pabst DA, Mclellan WA, Govett P, Harms C, Smolarek KA, Romero CH. 2006. A novel gammaherpesvirus associated with genital lesions in a Blainville's beaked whale (Mesoplodon densirostris). J Wildl Dis 42:142-148.

Smolarek Benson KA, Manire CA, Ewing RY, Saliki JT, Townsend FI, Ehlers B, Romero CH. 2006. Identification of novel alpha- and gammaherpesviruses from cutaneous and mucosal lesions of dolphins and whales. J Virol Methods 136:261-266.

Stewart REA, Campana SE, Jones CM, Stewart BE. 2006. Bomb radiocarbon dating calibrates beluga (Delphinapterus leucas) age estimates. Can J Zool 84:184-1852.

Van Bressem MF, Cassonnet P, Rector A, Desaintes C, Van Waerebeek K, Alfaro-Shigueto J, Van Ranst M, Orth G. 2007. Genital warts in Burmeister's porpoises: Characterization of Phocoena spinipinnis papillomavirus type 1 (PsPV-1) and evidence for a second, distantly related PsPV. J Gen Virol 88:1928-1933.

Van Bressem MF, Van Waerebeek K, Piérard GE, Desaintes C. 1996. Genital and lingual warts in small cetaceans from coastal Peru. Dis Aquat Organ 26:1-10.

van Elk CE, Van De Bildt MW, De Jong AA, Osterhaus AD, Kuiken T. 2009. Herpesvirus in bottlenose dolphins (Tursiops truncatus): Cultivation, epidemiology, and associated pathology. J Wildl Dis 45:895-906.

Submitted for publication 12 September 2013. Accepted 10 June 2014. 